\title{
Radiotelegraph communication of the Ukrainian People's Republic (UNR) of 1917-1921 as a fundamental basis for the founding of public radio broadcasting in Ukraine
}

\begin{tabular}{l|c|}
$\begin{array}{l}\text { Maiia Nahorniak, } \\
\text { Candidate of Philological Sciences, }\end{array}$ & $\begin{array}{c}\text { Citation: } \\
\text { PhD (Filology), }\end{array}$ \\
Associate Professor, Department & Nahorniak, M. (2021). Radiotelegraph \\
of Television and Radio Broadcasting, & Republic \\
E-mail: maya_nag@ukr.net, & (UNR) of 1917-1921 as a fundamental basis \\
https://orcid.org/0000-0002-2197-1338 & for the founding of public radio broadcasting in \\
https://www.researchgate.net/profile/Maya- & Ukraine. Social Communications: Theory and \\
Nahorniak & Practice, Vol. 13(2). DOI: 10.51423/2524- \\
Institute of Journalism, & $0471-2021-13-2-5$ \\
Taras Shevchenko National University of Kyiv, & Retrieved from \\
Yuri Ilyenko St., 36/1, Kyiv, & https://new.comteka.com.ua/index.php/journal/ \\
Ukraine, 04119. & Workflow/index/110 \\
& C Nahorniak, M. (2021). \\
\hline
\end{tabular}

\section{Annotation}

The purpose of the article is to study the issues related to the unexplored period of formation of the Ukrainian national radio broadcasting. It is about the proclamation and foundation of the Ukrainian People's Republic (UNR)1917-1921; to prove that radiotelegraph content serves as a prototype of modern public radio broadcasting in Ukraine. The research methodology involved the use of methods belonging to two groups: scientific and practical methods - method of studying archival materials, observation and description; scientific theoretical methods - formalization, axiomatization, analysis and synthesis, analogy. One of the first steps of the UNR government was creation of the Ministry of Posts and Telegraphs, which was engaged in the production of radiotelegraph content. It allowed for effective internal and external communication of the UNR government. The main form of content was numerous orders, orders, speeches, appeals, explanatory notes, which we consider a prototype of primary information messages. Results. One of the first steps of the UNR government was creation of the Ministry of Posts and Telegraphs, which was engaged in the production of radiotelegraph content. It allowed for effective internal and external communication of the UNR government. The main form of content was numerous orders, orders, speeches, appeals, explanatory notes, which we consider the primary information messages. Given the high social significance of radiotelegraph content, its extreme relevance in a controversial historical era, prompt delivery to the audience, a balanced approach to information, there is every reason to believe that radiotelegraph communication is a precursor to modern public radio broadcasting in Ukraine. Conclusions. Radiotelegraphic content of the Ukrainian People's Republic of the period 1917-1921 became the first information product of the young country's activity. Thanks to the production of this content, the first steps in providing it have been taken domestic and foreign institutions, communities with reliable, comprehensive information about the turbulent events of the First World War and the postwar years. Dissemination of important socio-political information by radiotelegraph and radio communication was considered a strategic task of the state. Having passed a long and painful way of its formation, the radiotelegraphic content of the period of the 
Ukrainian People's Republic of 1917-1921 later managed to produce purely radio methods and techniques of presenting information, which could not but affect the quality and effectiveness of providing the community with important and necessary socially significant information, which is the basis for the development of public broadcasting in Ukraine.

Key words: radiotelegraph, radiocommunication, radiotelegraphic content, information message, public radio broadcasting.

\title{
Радіотелеграфний зв'язок Української Народної Республіки (УНР) 1917-1921 років як фундаментальна основа становлення суспільного радіомовлення України
}

\author{
Майя Нагорняк, \\ кандидат філологічних наук, \\ дочент кафедри телебачення і радіомовлення \\ Інституту журналістики \\ Київського національного університету \\ ім. Тараса Шевченка \\ (м. Київ, Україна)
}

\section{Ветуп}

Проблема, яка розглядається в статті, може бути стисло викладена як повна відсутність знань про надзвичайно вагомий період становлення українського національного радіомовлення, пов'язаний iз проголошенням і утвердженням Української Народної Республіки (УНР) 1917-1921 років.

У широкому сенсі зазначена проблема містить кілька аспектів, до яких ми відносимо такі:

1) невивченим $є$ питання того, як саме в буремні часи Першої світової війни 1914-1918 років зародження потужного технологічного явища радіотелеграфного зв'язку вплинуло на проголошення й утвердження Української Народної Республіки (УНР) 1917-1921 років;

2) нез'ясованим є питання ролі радіотелеграфного зв'язку у функціонуванні новоутвореної Української держави (УНР) 1917-1921 років;

3) невивченим є питання суб' єктності діяльності радіотелеграфного зв'язку;

4) невивченим є питання виробництва радіотелеграфного контенту, який уважаємо первинним інформаційним радіопродуктом, а також прообразом сучасних новинних радіоповідомлень;

5) невивченим $є$ питання того, що радіотелеграфний зв'язок став предтечею формування й становлення суспільного радіомовлення України.

У статті ми здійснюємо спробу подати відповіді на згадані запитання.

Аналіз попередніх досліджень і публікащій.

Оскільки становлення українського національного радіомовлення в контексті проголошення й утвердження Української Народної Республіки (УНР) 1917-1921 років не досліджувалося іншими вченими, ми змушені скористатися декількома власними публікаціями, які вийшли друком у 2018-2019 роках. Також ми маємо звернути увагу на той факт, що, за нашими спостереженнями, до виходу із друку цієї статті з-поміж відомих нам публікацій питання радіотелеграфного зв'язку УНР 1917-1921 років як фундаментальної основи становлення суспільного радіомовлення не обговорювалося. Отже, ми звертаємося до аналізу зазначених публікацій, а також тих, зміст яких кореспондується зі згаданою вище проблемою.

Миронченко В. (Миронченко, 1989) дотримується думки, що історія українського національного радіомовлення традиційно провадить свій відлік від 20-х років ХХ століття. В одній із праць він зауважує, 
що інформаційна діяльність радянського радіо, із якого бере витоки, зокрема, й українське національне, розпочалась у буремні дні жовтня 1917 року. Учений наголошує, що за допомогою радіо перші вісті про перемогу Жовтневої революції стали поширюватися і в Україні. Після повалення Тимчасового уряду, за твердженням науковця, передача по радіо інформації, адресованої найширшим масам населення, поступово стає щоденною практикою. Прийняті по радіо телеграми, заклики та звернення до армії й населення, декрети радянської влади друкувались у центральних і місцевих газетах, випускались у формі листівок, радіобюлетенів. Цей факт $є$ безпрецедентним із точки зору визначення пріоритетності тогочасних медіа: спершу повідомлення пройшло каналами радіо, пізніше - на друкованих носіях, зокрема й носіях рекламного характеру.

Деякі дослідники, зокрема Митрофанов Н. (Митрофанов, 1980), вважають, що чимало виступів радіотелеграфних станцій зафіксовані ще в період підготовки революції, тобто до переломного 1917 року. За його словами, станції передавали в ефір заклики та звернення до революційного народу. Повертаючись до згадуваного Миронченка В. (Миронченко, 1984: 8), важливо зауважити, що в іншій своїй роботі він наголошує на тім факті, що сучасне інформаційне радіомовлення бере початок від радіогазет, які були створені за ленінською ідеєю про «газету без паперу» і «без відстаней». Перший випуск «Радіогазети РОСТА» було передано через московську радіостанцію ім. Комінтерну 23.11.1926 р. Дослідник дотримується думки, що ця дата є початком регулярного радіомовлення в Україні.

Відправною точкою в започаткуванні українського радіомовлення уважається 16.11 .1924 року, коли в ефір вийшла перша радіопередача. Ідеться про те, що цього дня о 19.00 з рупорів м. Харкова пролунало: «Алло, алло! Говорить Харків! Працює перша в Україні радіотелефонна станція». Після того було передане звернення керівника уряду В. Чубаря, а також прозвучав концерт державного музичного квартету імені Вільома й радіожурнал «Пролетар» (Про Українське радіо, 2021).

Хоч 1924 рік і береться за основу, слід віддати належне тому фактові, що аж за п'ятнадцять років до цього закладався міцний підмурівок радіомовлення. Маємо на увазі здійснення спроб налагодити зв'язки між різними господарськими об'єктами за допомогою радіотелеграфу. Щоправда, це стосується Російської імперії, до складу якої входили тоді й українські землі. За словами Ружникова В. (Ружников, 1987: 29), головне управління пошти й телеграфів Росії ще аж у 1909 році почало будувати перші комерційні станції. Вони були встановлені на берегах Білого, Балтійського, Чорного та Каспійського морів, ПівнічноЛьодовитого й Тихого океанів. Станції мали незначну потужність через обмежене призначення й використання, а саме - підтримувати радіозв'язок одна з одною, а також із суднами, що проходили повз. Дослідник зазначає, що наприкінці Першої світової війни головне управління пошти й телеграфів мало у своєму розпорядженні близько 30 радіостанцій (Ружников, 1987: 29-30).

Говорячи про великі російські радіостанції того часу, звертаємо особливу увагу на те, що 1914 року 3'явилася й одна 3 перших радіостанцій на українських теренах імперії. Радіо функціонувало в м. Миколаєві в районі ракетного урочища. До речі, поблизу колишнього ракетного заводу встановлений пам’ятний знак про те, що на початку Першої світової війни тут працювала радіостанція. Зауважмо, що Миколаївська радіостанція була третьою за потужністю в Російській імперії після Царськосельської та Московської.

Із точки зору технологічних характеристик станція використовувала 16 стометрових антен і новітню на той час апаратуру фірми «Марконі» потужністю 100 кіловат із радіусом дії понад сім тисяч верст. Вона активно залучала до своєї діяльності війська Антанти, денікінців, більшовиків, тому й дістала назву «Миколаївська потужна радіостанція міжнародних відносин». 1922 року припинила існування, апаратуру перевезли до Харкова, де обладнали велику радіостанцію для потреб тодішньої української столиці.

Дослідники радянського періоду радіо Лизанчук В. (Лизанчук, 2000), Миронченко В. (Миронченко, 1989), Прокопенко I. (Прокопенко, 1983), Нужний В., Щербатюк В. (Нужний, Щербатюк, 1965), Багіров Е. (Багіров, 1984), Дубровін В. (Дубровін, 1972), Гуревич П. (Гуревич, 1976), Ружников В. (Ружников, 1987), 
Шерель О. (Шерель, 2000) та інші акцентують увагу на широкому використанні можливостей нового виду зв'язку більшовиками на чолі з В. Леніним.

Багіров Е., Ружников В. (Багіров, Ружников, 1984) якраз і наголошують на тім, що соціалістична революція, яка перемогла в Росії, активно застосовувала радіо насамперед як засіб оперативного оповіщення широких народних мас про діяльність і політику першої у світі держави робочих і селян, а також як інструмент регулярного зв'язку із трудящими зарубіжних країн (Багіров, Ружников, 1984: 7).

У цьому зв'язку Ружников В. (Ружников, 1987) у своїй праці підтверджує згадану тезу фактом. 25.10. (07.11.) 1917 р. радіо крейсера «Аврора» передало перші повідомлення про перебіг Жовтневого перевороту, який у радянській історії дістав назву «Велика Жовтнева соціалістична революція». На радіостанцію було відправлено відозву В. Леніна «До громадян Росії». Після радіостанції крейсера «Аврора» документ потрапив до Архангельської радіостанції й уже звідти надісланий до Москви. Важливо зауважити, що Архангельська станція продублювала повідомлення в ефірі, а за деякий час документ уже був поширений серед москвичів у друкованому варіанті (листівка). Цей факт ще раз доводить тезу про визначення радіо як першого медійного пріоритету Російської імперії часів перевороту.

Дубровін В. (Дубровін, 1972) вважає надзвичайно промовистою наступну комунікаційну ситуацію. Вождь пролетаріату активно використовував можливості радіо в ніч проти 08.11. (21.11) 1917 р., коли намагався усунути з посади верховного головнокомандувача, заколотного царського генерала М. Духоніна та розповісти про це солдатам. Учений наголошує на тім факті, що Декрет про мир, ухвалений на II з'їзді Рад, саботувався ставкою генерала, який через різні причини відмовлявся провадити переговори щодо перемир'я. Якраз у ніч проти 08.11. (21.11) В. Ленін підписав радіотелеграму Раднаркому про перемир'я 3 командуванням австро-угорських військ; при цьому головнокомандувач не відповів ані на радіотелеграму, ані на телефонограму. Черговим повідомленням він попередив військового керівника про відповідальність за зрив перемовин, що теж не дало результату. Тоді Ленін вирішив використати радіо задля звернення до солдатів через голову командування (Дубровін, 1972: 18).

Таке своєрідне радіоспілкування керівника молодої радянської держави та царського генерала дозволяє переконатися в тім, що в часи перевороту новий технічний засіб зв'язку завдяки своїй всеосяжності демонстрував колосальні функціональні потужності, унаслідок чого стало можливим представити політичні позиції тогочасних політичних ньюсмейкерів.

Також Дубровін В. (Дубровін, 1972) зазначає, що в ніч проти 08.11. (21.11) лідер більшовиків разом із іншими учасниками перемовин прибув на радіостанцію «Нова Голландія», де підготував звернення до громади. У радіотелеграмі він закликав усі полкові, дивізійні, корпусні, армійські комітети, а також усіх солдат революційної армії та матросів революційного флоту обирати уповноважених для започаткування перемовин щодо перемир'я з ворогом. Ленінська радіотелеграма була повторена багатьма радіостанціями більшовицької Росії, іï також прийняли сотні фронтових радіостанцій. За словами дослідника, це був перший в історії випадок звернення до мільйонів людей за допомогою радіо (Дубровін, 1972: 19).

Необхідно зазначити, що передача подібних відозв, звернень, приписів тощо за допомогою радіотелеграфу в часи Жовтневого перевороту вважається першим досвідом використання радіо як технічного засобу зв'язку для досягнення ідеологічних цілей партією більшовиків. Надалі радіотелеграф стає ще більш оперативним, надійним і зручним засобом спілкування партії й влади з населенням.

Зважаючи на означене, правомірно доходимо висновку про те, що радіотелеграфний період $\epsilon$ першопочатковим і надто важливим етапом розвитку радіо, що становить основу започаткування його діяльності на теренах Росії. Передача на відстані різного роду суспільно-політичних матеріалів стала первісною формою спілкування влади з людьми. Звісно, ці передавання були суто технічним процесом, завдяки своїм функціональним особливостям вони заклали підмурівок подальшого розвитку радіотелеграфної комунікації. На цьому зосереджує увагу Лизанчук В. (Лизанчук, 2006). Феномен радіо, на думку вченого, полягав у доступності сприйняття живої мови та в блискавичній оперативності повідомлень, а також у своєрідній сакральності мовленого, що звучало, здавалося, ледь не з піднебесся, 
сприяв всезростаючій популярності нового технічного засобу масової інформації. Відповідно до офіційно оголошеної доктрини зростання політичної самосвідомості трудящих мас було неможливим без добре налагодженого їхнього інформування про найвагоміші події в країні та поза їі межами (Лизанчук, 2006: 16).

Як бачимо з викладеного вище, упродовж усього радянського періоду становлення радіомовлення події, які відбувалися у 20-х роках ХХ століття, досліджувалися й українськими, і російськими вченими виключно з позицій жовтневого перевороту, діяльності радянської влади й більшовиків на чолі з В. Леніним, тобто в тісному зв'язку з тогочасним політичним контекстом, визначеним комуністичними агітацією та пропагандою. Питання ж проголошення й утвердження Української Народної Республіки (УНР) 1917-1921 років, функціонування і впливу радіотелеграфного зв'язку на державотворчі процеси в ній не вивчалися суто через ідеологічні причини. Навдивовижу, але факт залишається фактом: за умов незалежної України зазначені теми також не знайшли свого відображення в працях дослідників радіокомунікацій, що, на наш погляд, $є$ істотною прогалиною в історії вітчизняного радіомовлення, адже, як слушно зауважує в цьому зв’язку Лизанчук В., влада засобів масової інформації є набагато сильнішою, глибшою, аніж законодавча, виконавча чи судова, бо тримає у своїх руках свідомість і дух людини (Лизанчук, 2006: 14).

\section{Методи й методики дослідження}

У подальшому дослідженні, на нашу думку, є доречними методи двох груп, а саме: наукові практичні та наукові теоретичні методи.

Серед наукових практичних методів валідними для досягнення поставленої мети вважаємо метод вивчення архівних матеріалів, метод спостереження й метод опису.

Метод вивчення архівних матеріалів на прикладі Центрального державного архіву вищих органів влади та управління України дозволив здійснити пошук, ознайомлення, класифікацію й систематизацію вагомої історичної інформації, пов'язаної з діяльністю Української Народної Республіки (УНР) 19171921 років. У межах цього методу застосовано три інших, а саме: логічний, аналітичний, хронологічний, що дало змогу розглянути архівні відомості крізь призму тезаурусного підходу. Наукове розкриття змісту архівних документів базується на основних принципах: історизму, усебічності й комплексності.

Метод спостереження було застосовано нами як цілеспрямоване й організоване сприйняття відомостей, поглядів і положень про історичний період проголошення й утвердження УНР 1917-1921 років, специфіки й особливостей суспільно-політичних і соціально-економічних явищ, процесів, тенденцій означеної доби. Водночас ми використали метод опису з метою здійснити фіксацію результатів згаданих спостережень.

Наукові теоретичні методи, які допомогли здійснити це дослідження, були такі: формалізація, аксіоматизація, аналіз і синтез, аналогія. Метод формалізації дозволив напрацювати орієнтовну схему, яка розкриває сутність радіотелеграфного зв'язку як фундаментальної основи становлення суспільного радіомовлення України. Завдяки методу аксіоматизащії ми висунули низку положень, які не потребували доведення й вивели на їхній основі тези, що утворили аксіоматичні відомості щодо радіотелеграфного зв'язку як предтечі формування суспільного радіомовлення України. Методи аналізу й синтезу сприяли тому, що спочатку ми розділили поняття «радіотелеграфний зв'язок», «масове регулярне радіомовлення», «інформаційне радіомовлення», після чого з’єднали в єдину концепцію щодо тлумачення терміна «радіотелеграфний зв'язок як фундаментальна основа становлення суспільного радіомовлення України».

Також під час здійснення дослідження було використано метод аналогії, який дав можливість сформулювати висновки про подібність ознак (наприклад, у системі «радіотелеграфний зв'язок» та «суспільне радіомовлення»). 


\section{Результати й обговорення}

Задля розуміння архіважливості явища радіотелеграфного зв'язку в 20-х роках XX століття та його впливу на тогочасні суспільно-політичні, соціально-економічні й міжнародні трансформаційні процеси на українських теренах та закордоном мусимо здійснити екскурс в історію, без чого подальше вивчення питання є не можливим. Здійснюємо спробу поглянути на вкрай складний, суперечливий період 19171921 років крізь призму тогочасної загальної суспільно-політичної ситуації, національно-визвольних рухів України, а також тих подій, які відбувалися на українських територіях: Першої світової війни, Української революції, утворення Української Народної Республіки (УНР). У зв’язку із цим апелюємо до думки українського історика, громадського та політичного діяча, голови Центральної Ради Української Народної Республіки (1917-1918рр.) Михайла Грушевського. За його твердженням, до згаданих епохальних перетворень українство підійшло в стані великої руїни. Як зазначають історики Литвин В., Левенець Ю., Смолій В., Шаповал Ю. та інші (Литвин, Левенець, Смолій, Шаповал та інші, 2007) визначальну роль у цих процесах відігравали сусідні країни, інтереси яких були такими. Російські великодержавники прагнули скористатися Першою світовою війною, щоб покінчити 3 українським рухом. Націоналісти Польщі сподівалися, що заселення спорожнілих земель зміцнить польський елемент. На українській проблемі позначалася й дуже мінлива політика австро-угорської влади, що зумовлювалося наявністю в ній різних політичних угруповань. Великі політичні гравці світу розглядали Україну виключно як буферну зону між Австро-Угорщиною та Росією. Відповідно до цього українські землі розподілялися на три частини: одна мала лишатися в складі Австро-Угорщини, друга - стати територією Польщі й третя - формально незалежна - розглядалася як «сіра зона». У цій ситуації Україні відводилася роль піддослідного кролика, що мав бути з'їденим. Такі інтереси зазначених країн пояснювалися тим, що кожна 3 них керувалася суто хижацькою ідеологією - посилити свою територіальну присутність у світі, при цьому ані найменшим чином не зважаючи, ясна річ, на піддослідного кролика в особі України (Литвин, Левенець, Смолій, Шаповал та інші, 2007: 199).

Зауважмо, що ідеологи української державності, серед яких був згаданий нами М. Грушевський, усвідомлювали всю небезпеку, спричинену світовими політичними гравцями. Вихід із ситуації полягав у тім, щоб утворити власну модель майбутнього розвитку незалежної Української держави, адже українцям, якщо вони хотіли зайняти свою геополітичну нішу, що утворилася на російсько-німецькому та російськоавстрійському кордонах, була дуже потрібна власна модель самовизначення. Наголосимо на тім, що, на превеликий жаль, у жодній із запропонованих моделей (модель митрополита А. Шептицького, модель Спілки Визволення України та інші) вона не розглядалася як єдина (соборна) держава. Така роль відводилася лише Наддніпрянщині, про майбутнє українських земель у складі Австро-Угорщини не йшлося, або ж для них передбачалася територіально-національна автономія.

До слова сказати, такі вкрай непевні політичні устремління накладалися на суворі реалії Першої світової війни. Ідеться про вкрай виснажену економіку, наслідком чого стала потужна розруха. Поневіряння, що випали на долю зубожілих людей, позначилися на їхніх суспільних настроях. Найширші верстви населення України вбачали для себе вихід лише в одному - революції. У цьому зв'язку історики розглядають Першу світову війну в подвійному ракурсі: як новий акт трагедії для українського народу і як початок доби національного самовизначення й самоствердження. Цей час був напрочуд трагічним, оскільки імперії, з одного боку, не усвідомлювали глибину національних рухів і небезпеку, пов'язану 3 ними. Із другого боку, національна еліта, що була слабкою, не змогла скористатися історичним шансом, який полягав у необхідності згуртувати спільноту навколо національної ідеї й створити хоча б теоретичну модель повоєнної України (Литвин, Левенець, Смолій, Шаповал та інші, 2007: 199).

Потрібно наголосити на тім, що на рівні масової свідомості, за словами істориків Литвина В., Левенця Ю, Смолія В., Шаповала Ю. та інших, ситуація була ще складнішою й заплутанішою. 
Розчленований народ, територія якого стала плацдармом не бачених доти битв, перебував у шоковому стані, не розуміючи сенсу кривавого побоїща й утративши орієнтири, що розділяли братів і ворогів. Попри зазначене, найважливішим стало те, що війна створила умови для артикуляції ідеї української незалежності та ії донесення до європейської політичної свідомості. У такому стані Україна підійшла до революції в Росії у лютому 1917 року (Литвин, Левенець, Смолій, Шаповал та інші, 2007: 218).

Звістка про повалення самодержавства в Росії миттєво поширювалася українськими землями. Повсюдно провадилися мітинги, демонстрації, з'являлися різні самочинні організації на кшталт рад робітничих, селянських, солдатських депутатів тощо. Фахівці схильні вважати, що український рух після повалення царату мав вибуховий характер, що означало нову стадію історичної боротьби українства. Говорять навіть, що це був період національно-демократичної революції, адже саме в той час у Києві відбувалося багато демонстрацій, у яких брало участь понад 100 тисяч осіб. Зауважмо, що пропаганді ідей Української революції прислужився випуск перших українських газет. 19.03.1917 року побачив світ перший номер газети «Вісті з Української Центральної Ради», також виходили видання «Нова Рада», «Робітнича газета». Незважаючи на чималу медійну підтримку, Українська революція не мала впевненого поступу, бо повсякчас наштовхувалася на великодержавний шовінізм: прихильники єдиної й неподільної Росії вважали Україну виключно своєю територією і ніяк не могли змиритися 3 iї волелюбними прагненнями (Литвин, Левенець, Смолій, Шаповал та інші, 2007: 229).

Своєрідним підтвердженням стану українського руху стало ухвалення I Універсалу, оголошеного Українською Центральною Радою (УЦР). Цим документом засвідчувалося, що, з одного боку, народ України відтепер буде вільним, сам облаштовуватиме своє життя завдяки Українським установчим зборам, а з іншого боку, декларувалася нерозривність із Росією, вирішення всіх питань державності покладалося на Всеросійські установчі збори. Таким чином, парадоксальний характер I Універсалу був очевидним. Українські історики наголошують, що УЦР не могла в той час вийти зі сфери могутнього впливу загальноросійської революції. Особливі умови розвитку суспільного руху в Україні й національний момент виявилися не настільки сильними, щоб знищити або хоч суттєво зменшити залежність Української революції від Жовтневого перевороту. На переконання дослідників, УЦР у вирішальний, зламний момент, коли обиралися шляхи подальшого суспільного розвитку, не мала ще достатньо визначеної позиції. У ії діяльності знову далася взнаки парадоксальність світоглядних поглядів: лідери Української революції дотримувалися соціалістичного курсу та водночас намагалися спрямувати очолюваний ними рух у загальноросійське русло (Литвин, Левенець, Смолій, Шаповал та інші, 2007: 26).

На основі викладеного вище вважаємо за необхідне окреслити основні тези, у яких подаються беззаперечні відомості щодо історичного періоду, що передує проголошенню УНР, стосується безпосередньої появи республіки й початку діяльності такого суб'єкта урядової влади, як Міністерство пошт i телеграфів. Саме ця структура активно використовувала радіотелеграфний зв'язок для цілеспрямованого, організованого та систематичного пропагування нової держави як у її середині, так i ззовні, що розглядаємо як передтечу суспільного радіомовлення України.

1.1. Надзвичайна розбурханість, неоднозначність і суперечливість тогочасної суспільно-політичної міжнародної обстановки, унаслідок якої Україна стала заручником політичних інтересів крупних гравців світу, що накладало відбиток на всі сфери життєдіяльності й чинило переважно негативний вплив на країну й спільноту.

2.2. Слабкість еліти, відсутність у неї політичної волі, хронічна неспроможність об'єднатися навколо національної ідеї та внаслідок цього надмірне дрейфування в бік Росії.

3.3. Дуже важке економічне становище держави й українства, що паралізовувало й унеможливлювало здатність до боротьби за високі державотворчі цілі.

4.4. Глибокі дезорієнтованість, розпачливість і розгубленість спільноти, що створювало доволі потужне негативне психологічне тло в суспільстві. 
5. Хоч більшовицький переворот у Петрограді ще більшою мірою посилив загальну кризу влади в Києві, однак завдяки цілеспрямованій діяльності УЦР Київ поступово перетворювався на загальноукраїнський політичний центр. 07.11.1917 року на засіданні Малої ради УЦР М. Грушевський уперше поставив питання про проголошення Української Народної Республіки. Він зауважив, що в момент відсутності центральної влади, розпалу громадянської війни, щоб боронити здобутки України, треба мати міцну підвалину, і такою підвалиною може бути тільки проголошення Української Народної Республіки. Після чого було зачитано Універсал, згідно з яким проголошувалося створення УНР у федеративному зв'язку з Російською державою.

Говорячи про адміністративно-територіальний устрій, необхідно наголосити на тім факті, що демократичні підвалини Української Народної Республіки було викладено в проєкті Конституції УНР. Відповідно до цього країна була складовою частиною федеративної Російської республіки, але суверенне право на їі території належало українському народові й здійснювалося через Всенародні українські збори. Збори утворювали вищу виконавчу владу (кабінет міністрів). Третьою гілкою влади мав бути Генеральний суд. Територія України оголошувалася неподільною й складалася із земель, яким було надано право самоврядування. Також широкі політичні права та свободи отримували громадяни України (Литвин, Левенець, Смолій, Шаповал та інші, 2007: 270-272).

Виконавчу владу в УНР представляла Рада народних міністрів, і з-поміж інших міністерств відразу ж було створено Міністерство Пошт і Телеграфів. Першим керівником відомства в уряді Володимира Винниченка (січень 1918 р.) став Микита Шаповал. Формування даної інституції розглядаємо як вагомий крок на шляху до налагодження системи ефективних комунікацій першого українського уряду зі своїми громадянами, а також закордонним українством, урядами інших країн тощо. Це стало природним кроком, адже без забезпечення належного зв'язку Києва з околицями, зі столицями європейських держав не могло бути й мови про розвиток української державності. Суб'єктність у процесах установлення й використання радіотелеграфного зв'язку можна відобразити в такій схемі:

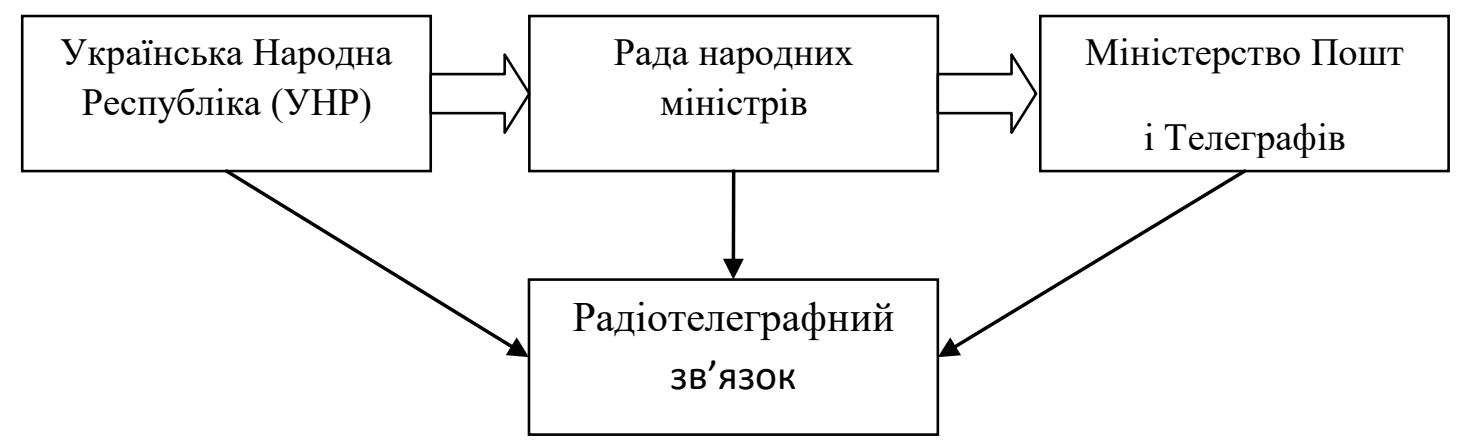

Для чіткого розуміння розділимо поняття «радіотелеграфний зв'язок», «масове регулярне радіомовлення» та «інформаційне радіомовлення». Отже, щодо радіотелеграфного зв'язку, то він правомірно вважається одним із найстаріших способів передачі інформації технічними засобами (за допомогою електричних й оптичних сигналів) на великі відстані. Масове регулярне радіомовлення - це виробництво й поширення аудіопродукту для широкої аудиторії, що відбувається 3 певною періодичністю; це також інформаційна галузь, що набула ознак глобального медіа та $є$ засобом впливу на громадськість. Під інформаційним радіомовленням ми розуміємо процеси, зумовлені збором, відбором, обробкою та поширенням суспільно значущих відомостей з усіх сфер життєдіяльності України та поза іiі межами, які розповсюджуються з високою частотністю для споживачів продукту.

Звернімо увагу на те, що роботу Міністерства Пошт і Телеграфів УНР від самих початків було поставлено в жорсткі організаційні рамки. Радіотелеграфний зв'язок став новітнім явищем тієї доби, 
через що працівники, залучені до передачі повідомлень, часто-густо зловживали ним. Про це свідчить розпорядження міністра М. Шаповала від 31 грудня 1917 року №1013 щодо встановлення прямих дротів і дозволи розмов, про затримання приватних телеграм, адресованих усім секретарствам: «На основі постанови Генерального Секретарства прошу спинити видачу дозволів на розмову по прямих дротах, бо розмовники страшенно зловживають часом і телеграф майже не виконує своїх прямих обов'язків. Дозволи на розмови по прямих дротах прошу брати в Генеральному Секретаріаті пошт і телеграфів. Сегодня мною зроблено роспорядок що до прямих дротів допускаються без дозволу тільки Генеральні Секретарі та їх товариші (заступники - авт.). Генеральний секретар Пошт і Телеграфів М. Шаповал». Стилістику документа збережено (Центральний державний архів вищих органів влади та управління України. Ф № 2592, опис № 1, справа № 10, с. 6).

Документ переконує в тім, що урядовці Української Народної Республіки як істинні державники надавали великого значення встановленню комунікаційних зв'язків між урядом УНР та урядами інших держав, а також налагодженню внутрішніх контактів між усіма міністерствами, через що приділяли велику увагу організації цих процесів. Власне, перемовини очільників уряду в нагальних службових потребах за допомогою прямих проводів, намагання впорядкувати їхнє функціонування можна розглядати як напрацювання своєрідного радіотелеграфного контенту. Звісно, інформація подібного штибу була доволі специфічною (відрізнялася офіціозністю й протокольністю), проте можна стверджувати, що саме це стало тим ядром, завдяки якому сформувався підмурівок масового регулярного радіомовлення.

Необхідно зауважити, що під час вивчення матеріалів Центрального державного архіву вищих органів влади та управління України помічено таке: чи не найбільше до Міністерства Пошт і Телеграфів було звернень від Міністерства Закордонних Справ. Ішлося про надання можливості поспілкуватися із представниками країн, зокрема Німеччини та Австро-Угорщини. Саме ці держави до березня 1918 року надавали УНР міжнародну підтримку, але після своєї поразки в Першій світовій війні країна позбулася цього. 3 огляду на зазначене, часті звернення зовнішньополітичного відомства були логічними й умотивованими, оскільки УНР установила дипломатичні стосунки з більше, ніж двадцятьма країнами; уряд запроваджував тісне міжнародне співробітництво 3 багатьма державами, прагнув заручитися підтримкою їхніх урядів, у такий спосіб утверджуючи себе на міжнародній арені. Очільники УНР були свідомі того, що тільки за умови цілеспрямованого й системного пропагування нової держави Україна може постати серед держав світу як цілісне й самодостатнє утворення.

Надзвичайно активна діяльність зовнішньополітичного відомства УНР відображена в документах. У службовій записці за № 982 від 4 квітня 1918 року йдеться про таке: «Міністерство закордонних справ доводить до Вашого відома, що йому потрібно мати прямий провід Київ-Берлін. Коли це можливо 3 технічного боку, МЗС просить Вас негайно вжити за для цього відповідні заходи і повідомити Міністерству про наслідки. Одночасно Міністерство закордонних справ звертається в цій справі до п. Германського посла» (Центральний державний архів вищих органів влади та управління України. (Фонд № 2592, опис № 1, справа № 10, с.15). Стилістику документа збережено. Через об'єктивні причини забезпечити такий зв'язок було неможливо, про що повідомлено наступним документом.

За деякий час (13 квітня 1918 року) листом № 1295 МЗС Української Народної Республіки надсилає звернення Панові Представникові Німецької держави Дійсному Тайному Радникові Фрайгерру ДраМумму фон-Шварценштейну. У ньому відомство наголошує на прикрій ситуації, яка трапилася із проводами (стилістику документа збережено): «Міністерство закордонних справ одержало від Міністерства Пошт і Телеграфів відомості що німецькі військові частини розрізують телеграфні дроти Київської сіті і проводять свої проводи, і що таким чином вже заняли на лінії Київ-Святошин проводи під № 32-99 і 4432. Маем честь прохати Пана Представника вжити відповідних заходів аби вищеназвані лінії освободжені і щоб надалі, коли німецьким частинам будуть потрібні проводи вони з тим звертались до Міністерства Пошт і Телеграфів котре зробить все можливе для їх задоволення. Управляючий Міністерством справ 
закордонних (підпис)» (Центральний державний архів вищих органів влади та управління України. Ф № 2592, опис № 1, справа № 10, с.15). Стилістику документа збережено.

Ситуація із забезпеченням прямого проводу Київ-Берлін була кепською. Уже за 2 дні (15 квітня 1918 року) у службовій записці № 1329 читаємо про ще одне прохання Управляючого Міністерством закордонних справ до Пана Представника Німецької Держави: «... просимо пана Представника негайно вжити заходів для полагодження означенної в телеграмі справи і зробити розпорядження німецьким властям аби при користуванні телеграфно-телефонними проводами вони не лишали почтово-телеграфної установи без безпосереднього зв'язку, а також не забирали всих транзитних проводів зв'язку Київа 3 польовими пунктами. Управляючий Міністерством справ закордонних (підпис)» (Центральний державний архів вищих органів влади та управління України. Ф № 2592, опис № 1, справа № 10, с.16-17). Стилістику документа збережено.

Слід віддати належне тому, що Міністерство Пошт і Телеграфів працювало на повну потужність, забезпечуючи державу якісною комунікацією. Це засвідчується вельми промовистим фактом - інституція мала у своєму розпорядженні радіостанцію, факт чого відображено в «Наказі про передачу Катеринославської дуженної радіостанції до Поштово-Телеграфного відомства. м. Київ, 25.07.1918 р. № 80». У документі йдеться про те, що «Згідно журнальної постанови Ради Народних Міністрів від 21.03.1918 p. за № 37, до Поштово-Телеграфного Відомства перейшла Катеринославська дуженна радіостанція 3 21.07. ц.р. Пропоную Начальникові Катеринославської Поштово-Телеграфної Округи, а також Начальникові Катеринославської радіостанції записати прийняте комісіею майно і матерьяли по відповідним книгам. За міністра Внутрішніх Справ Кулябко-Корецький (підпис)» (Центральний державний архів вищих органів влади та управління України. Ф № 3766, опис № 1, справа № 49, с. 189). Стилістику документа збережено.

Напрочуд чітка й злагоджена діяльність Міністерства Пошт і Телеграфів стала можливою завдяки звитяжній роботі його очільника Микити Шаповала. Він розумів, що добре організована робота радіотелеграфу сприятиме посиленню позицій УНР як у середині країни, так і поза їі межами. Вочевидь, усвідомлення чиновником виняткової важливості цієї царини суспільного життя обумовлювалося тим, що він був не лише політичним і громадським діячем, але й соціологом, публіцистом. У 1909-1914 роках М. Шаповал редагував часопис «Українська хата», написав близько 60 публіцистичних праць: «Революційний соціалізм на Україні» (1921р.), «Село і місто» (1926р.), «Масарик як соціолог» (також німецькою і чеською мовами), «Стара і нова Україна» (1926 р.), «Міжнаціональне становище українського народу» (1934 р.) та чимало інших. Міністр Пошт і Телеграфів також відомий і як письменник (під псевдонімом М. Сріблянський і М. Бутенко) опублікував поетичні збірки: «Сни віри» (1908р.), «Самотність» (1910р.), нариси «Жертви громадської байдужости» (1910р.), «Шевченко і самостійність України» (1917р.) та інші.

Становленню громадянської позиції пана Шаповала сприяла й дипломатична діяльність. Він виконував обов'язки секретаря дипломатичної місії УНР у Будапешті (1919-1920 рр.), розвинув жваву громадсько-політичну й культурну діяльність у Празі, де, заручившись підтримкою першого Президента Чехословаччини Т. Масарика, головував в Українському Громадському Комітеті, засновував українські вищі школи в Празі, був одним із співзасновників Української Господарської Академії в Подєбрадах, очолював Український Соціологічний інститут у Празі. Тож, ясна річ, людині з таким багатим життєвим, політичним і письменницьким досвідами вдалося налагодити діяльність увіреної йому безпрецедентно вагомої ланки - Міністерства Пошт і Телеграфів.

Вищезазначений факт знайшов підтвердження й у деяких інших службових документах доби УНР. Намагання встановити якісні комунікаційні зв'язки з Німеччиною, вивести перемовини очільників держав на належний технологічний рівень відображено в листуванні (докладі) Пана Директора Загального Департаменту до Начальника Бухгалтерсько-Господарчого відділу Міністерства Пошт і Телеграфів від 18 жовтня 1918 р. Стилістику документа збережено: «Вчера Міністерський телеграфний апарат Юза німецьким електротехніком получен з Німецькою Головною Телеграфною Станціею і таким робом вже 
можна балакати по прямому дроту з Берліном через Німецьке Оберкомандування. О сьому маю честь доложити Вам Пане Директоре і прохати належних розпоряджень аби негайно були командіровані Управління Пошт і Телеграфів урядовці Слізарів, Кривенюк і Арсенійчук, а також технік Клімков: перші три для виконування обов'язків телеграфістів, а останній для догляду за апаратом. Начальник бухгалтерсько-Господарчого відділу (підпис)» (Центральний державний архів вищих органів влади та управління України. Ф № 2592, опис № 1, справа № 10, с. 19). При цьому не можна не звернути уваги на те, яку важливу роль відводили організації належного комунікування в уряді УНР, відряджаючи обслуговувати телеграфний апарат Юза під час перемовин із Берліном аж трьох чиновників й одного техпрацівника.

Не все було так злагоджено, як це може здатися на перший погляд. За десять днів, а саме 28 жовтня 1918 року, листом № 1358 до Головного Управління Пошт і Телеграфів звертаються Міністр закордонних справ, Директор Загального Департаменту й Начальник Першого Відділу. Вони висловлюють занепокоєння технічним рівнем апарату Юза. Стилістику документа збережено: «Зважаючи на те, що апарат Юза, яким користуються Міністерство Закордонних Справ занадто слабий і говорити через цей апарат з далекими пунктами, як з Берлином і иншими неможливо, Міністерство мае за честь прохати Вас зробити розпорядження аби цей апарат було замінено в як найскоршім часі новим, більш здатним для роботи (підписи)» (Центральний державний архів вищих органів влади та управління України. Ф № 2592, опис № 1, справа № 10, с.21). Документів, у яких би йшлося про заміну згаданого пристрою, знайти не вдалося.

Українська Народна Республіка встановлювала комунікаційні зв'язки не лише з Німеччиною, але й 3 іншими державами світу, зокрема з Румунією. Про це свідчить звернення Директора Департаменту, Завідувача Загальним Відділом Міністерства Закордонних Справ до Міністерства Пошт і Телеграфів від 15 квітня 1918 р. за № 1347. Стилістика документа збережена: «МЗС повідомляє Вас, що для потреб Міністерства необхідно мати, якнайскорше, телеграфний зв’ язок /по апарату Юза/ з нашим послом в Ясах, про що він в Ясах також з свого боку подбае. Тому Міністерство просить Вас, по можливости негайно вжити в цій справі відповідних заходів і про наслідки повідомити (підписи)» (Центральний державний архів вищих органів влади та управління України. Ф № 2592, опис № 1, справа № 10, с. 22).

Невтішна відповідь Міністерства Пошт і Телеграфів не забарилася й надійшла на той час оперативно (за десять днів). У службовій записці до зовнішньополітичного відомства від 25 жовтня 1918 р. за № 43/270 ідеться: «В додаток до Вашого відношення від 17 квітня № 2059, повідомляю, що провід для безпосереднього зв'язку з Ясами, облагоджего тільки до Сорок, де всі провода перерізані по наказу Руминського коменданта. За товариша Міністра. В.О. Директор Департаменту (підпис)» (Центральний державний архів вищих органів влади та управління України. Ф № 2592, опис № 1, справа № 10, с.22). Стилістику документа збережено.

Отже, зазначені вище документи дають можливість переконатися в тім, що процес установлення міжнародних зв'язків УНР із країнами світу не був безпроблемним, він супроводжувався суперечливими, подекуди контроверсійними діями чиновництва згаданих держав.

Українська Народна Республіка встановлювала комунікаційні зв'язки не лише 3 далекими закордонними країнами, а й зі своїми найближчими сусідами, зокрема Росією. Налагодження співпраці відбувалося на рівні перемовин високих очільників держави щодо проведення представницьких заходів (як із Німеччиною і Румунією). В обох нижченаведених документах ідеться про нагальну потребу налагодити функціонування прямих проводів для того, щоб політики різних країн могли вільно спілкуватися й транслювати свої позиції спільноті. Про це свідчить службова записка Управління Міністерства закордонних справ до Міністерства Пошт і Телеграфів № 1541 від 20 квітня 1918 року. Стилістика документа збережена: «Міністерство Закордонних Справ прохае негайно сповістити у якім становищі знаходиться зараз прямий дрот до Курська. Як же він бува попсутий, то МЗС прохае, яко мога скорше, приступити до упорядкування його і сповістити МЗС коли се буде зроблено, позаяк 21 квітня у 
Курську мае відбутися Мирна Конференція Представників Української Народньої Республіки 3 Великоросійським урядом. Управління Міністерством Закордонних Справ» (Центральний державний архів вищих органів влади та управління України. (Ф № 2592, опис № 1, справа № 10, с.25).

Не вдалося знайти документ, у якому б містилася відповідь Міністерства Пошт і Телеграфів щодо цього запиту, але знайдено службову записку Міністерства закордонних справ до Телеграфного відділу Міністерства № 2604 від 27 травня 1918 року наступного змісту: «Міністерство Закордонних Справ прохае згідно договору негайно провести прямий провід для Російськоі Мировоі делегаціі, котра поміщається в м. Киіві Готель «Марсель». Одночасно Міністерство Закордонних Справ звертається в цій справі до Військового Міністерства. Управляючий Міністерства Закордонних Справ, Директор Департаменту, Завідуючий Загальним відділом (підписи)» (Ф № 2592, опис № 1, справа № 10, с.4). Стилістику документа збережено.

Забезпечення міжнародної співпраці УНР й країн світу, здійснене Міністерством Пошт і Телеграфів, можна схематично зобразити так:

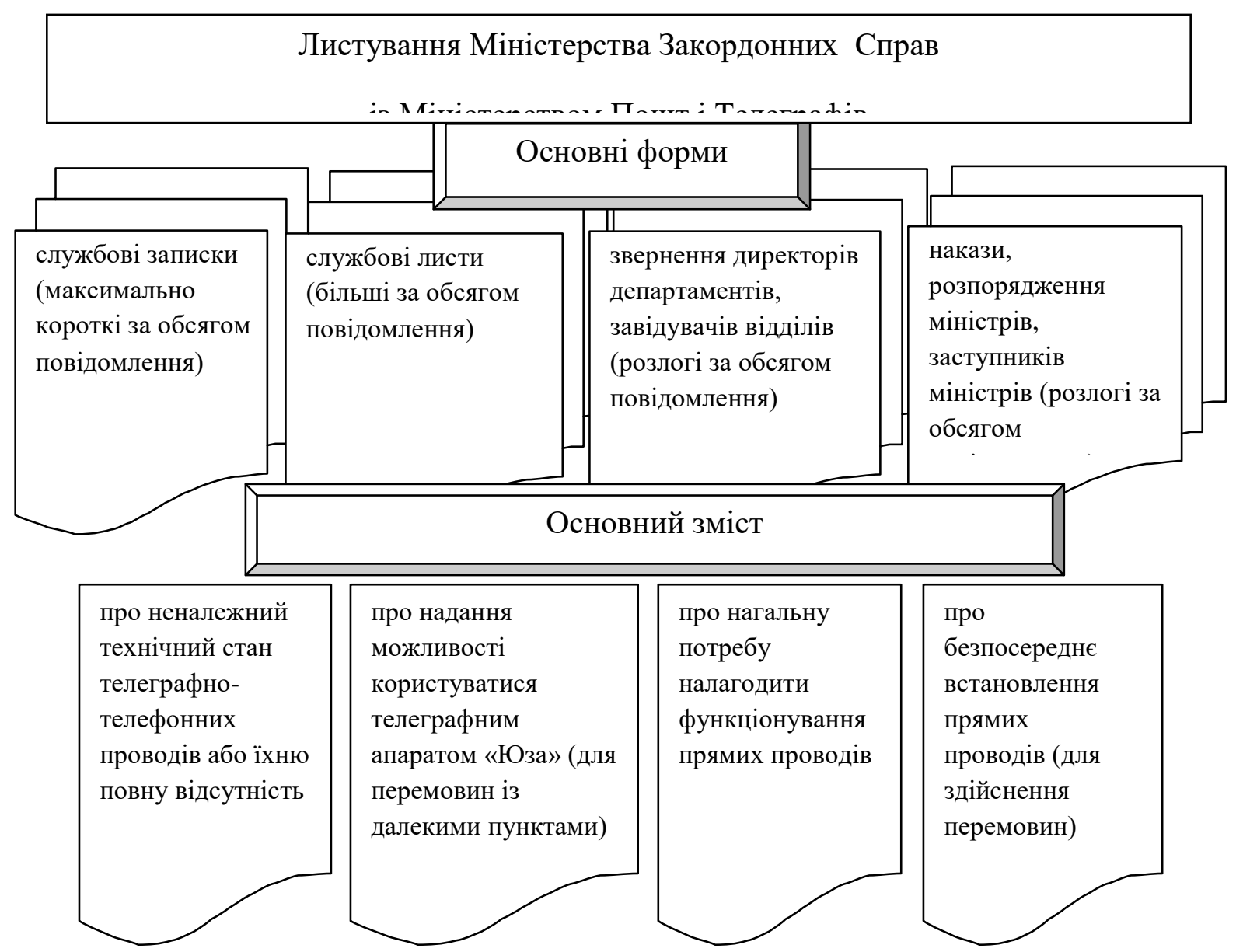

В Українській Народній Республіці велику увагу приділено дуже чутливій сфері життя всієї країни й кожного її громадянина - функціонуванню української мови. Понад сто років тому в державі вже були 
чітко визначені основні засади користування рідною мовою. Відповідний документ в обов'язковому порядку був розісланий в усі міністерства, відомства, інші суспільні інституції. Ідеться про «Наказ про вживання в слові і пісьмі Державноі Українськоі мови по Поштово-Телеграфному відомству Міністра Внутрішніх Справ. м. Київ, 26 липня 1918 р. № 81». Стилістика документа збережена: «В Українській Незалежній Самостійній Державі державною мовою визнаеться мова українська. Зважаючи на се, наказую Начальникам Округ звернути особливу увагу, щоб співробітники Відомства на пошті i телеграфі, радіотелеграфі і телефоні при виконанні службових обов'язків вживали лише української мови і вжити всіх заходів при зносинах по всіх службових справах зо всіма державними і приватними установами, а також урядовими особами переписку провадити виключно державною мовою; звернути також увагу, що коли в Відомстві ще е співробітники, які до сього часу не володіють українською мовою, щоб вони поважно подбали про швидче її вивчення. Нові співробітники, які будуть призначатися на посади по Відомству, мусять володіти як в слові, так і в пісьмі державною мовою. За Міністра Внутрішніх Справ Кулябко-Корецький (підпис)» (Центральний державний архів вищих органів влади та управління України. Ф № 2592, опис № 1, справа № 10, с. 188).

Піклування про те, щоб усі співробітники уряду Української Народної Республіки використовували у своїй роботі українську мову переконує в тім, що очільники керувалися національними інтересами, володіючи при цьому державним мисленням. Справу утвердження українськості було поставлено в порядок денний усіх без винятку суспільних інституцій, і немає нічого незвичайного в тім, що вирішення питання починалося саме із представників влади.

У цій вагомій справі радіотелеграфний зв'язок прислужився чи не найліпшим чином, адже завдяки йому згаданий «Наказ про вживання в слові і пісьмі Державноі Українськоі мови по ПоштовоТелеграфному відомству Міністра Внутрішніх Справ по Поштово-Телеграфному відомству. м. Київ, 26 липня 1918 р. № 81» було поширено серед чиновництва УНР, а це сприяло його популяризації серед широких верств населення. У вищезазначеному вбачаємо подібність ознак у системі «радіотелеграфний зв'язок» та системі «суспільне радіомовлення», оскільки природа обох систем спрямована на задоволення інформаційних, освітніх і культурницьких потреб спільноти. Крім цього, радіотелеграфний зв'язок і суспільне радіомовлення орієнтовані на оперативне та своєчасне надання важливої інформації широким верствам населення.

Користаючись методом аналогії, можемо провести паралелі між практичним утіленням у життя країни й спільноти засад мовної політики понад сто років тому і нині. Зважаючи на панування радянської системи цінностей, цілеспрямовано пропагованих комуністичною партією й радянською владою впродовж майже всього XX століття, відсутність стратегії розвитку української мови як державної після проголошення незалежності України та на рубежі XXI століття, питання її функціонування постало особливо гостро в другому десятилітті XXI століття, а надто в період російсько-української війни (Василенко, 2014) що почалася 2014 року й триває досі.

Саме тому в Україні назвали історичним рішення Верховної Ради від 25 квітня 2019 року щодо ухвалення закону «Про забезпечення функціонування української мови як державної». Закон зміцнює позиції державної мови в Україні, деталізуючи іï державний статус і практичне використання. Згідно із цим документом українська мова повинна домінувати в державному секторі й органах місцевого самоврядування, комунальному секторі та на підприємствах усіх форм власності, у громадських та інших організаціях, в освіті та науці, медицині, сфері послуг, енергетиці та промисловості, у кіно, театрі та медіа, діяльності війська, силових структурах. Відповідно до закону громадяни України зобов'язані володіти українською мовою на базовому рівні, однак за незнання мови для них не передбачено жодних санкцій. Інша річ, що без іспиту з української на базовому рівні жоден іноземець чи особа без громадянства не зможе стати громадянином України. Що ж до посадовців та представників бізнесу, освіти, медицини чи сфери послуг, то їх перевірятимуть на дотримання мовного закону (Ухвалено новий закон про мову. Перелік основних положень, 2021). 
Згаданий приклад укотре дає нам можливість переконатися в беззаперечній істині - невивчені уроки з історії українського державотворення здатні повертатися знову, але щоразу з новою силою. У цьому зв'язку не можемо оминути й наступного факту, пов'язаного 3 налагодженням системи цілеспрямованого інформування людей. Щоб інформація про найважливіші події в УНР і поза її межами надходила до громадян безперебійно, тим самим забезпечуючи ефективність сприйняття, 28.03.1918 року було створено Українське Державне Телеграфне Агентство (УДТА), що відображено у зверненні дирекції УДТА до Генерального Писаря (стилістику збережено): «Пану Генеральному Писарю Дірекція Украінського Державного Телеграфного Агентства

Високоповажний Пан! Цим маемо за честь довести до Вашоі відомости що Украінське Державне Телеграфне Агентство завтра 28.03. починає свою діяльність. Щиро просимо зробити распорядження в підвластній Вам інституціі щоб всі відомости, які мають мають бути опубліковані, пересилалися негайно до Дірекціі Украінського Державного Телеграфного агентства по цій адресі: Хрещатик, 25, кімн.11» (Центральний державний архів вищих органів влади та управління України. Ф № 1064, опис № 1, справа № 32, с.17). Цікаво знати, яким був зміст надісланих повідомлень. Так в одному з обіжників (огляді авт.) Телеграфного Агентства було вміщено такі вістки:

1). Новий склад Уряду УНР;

2). Нове товариство;

3). На увагу повстанцям;

4). Як мед, той ложкою;

5). Тікають;

6). Війна без зброї;

7). Настрій в Камянецькому повіті;

8). Як власна большевицька преса пише про повстання;

9). Нова організація в Совдепії;

10). Боротьба міст з селом.

11). Будують міста;

12). Давай Петлюру!;

13). Шляхом Гетьмана;

14) Економичний стан промисловости;

15) Босе місто;

16). Спростування про капетуляцію У.Н.Р.;

17). Далі вже нема куди;

18). Українська церква;

19). Стан урожаю;

20). Спростування про Модеста Ливицького;

21). Збрихали;

22). Шахрайство на голоді;

23). Академія Наук в Киіві;

24). Жидівська еміграція;

25). Товарообмін з примусу;

26). Програма Правительства У.Н.Р. (Стилістику збережено) (Центральний державний архів вищих органів влади та управління України. Ф № 1113, опис № 2, справа № 222, с.56).

Отже, 26 відомостей за тематичною спрямованістю розподіляються таким чином: 16 присвячено суспільно-політичній проблематиці, 8 відтворюють особливості соціально-економічного становища та у 2-х повідомленнях ідеться про духовне й наукове життя. До цього варто додати, що в інших оглядах новин, підготовлених Українським Державним Телеграфним Агентством, охоплювалися події практично 
всіх сфер суспільного життя: політики, економіки, міжнародної діяльності, сільського господарства, науки, освіти, релігії, міграційних питань тощо.

Крім того, Агентство готувало розлогі звіти про поточну ситуацію в Україні на підставі відомостей, зібраних позаштатними авторами, себто людьми на місцях, і з огляду на цю обставину подібним новинам можна було довіряти повною мірою. Наприклад, один із таких звітів зробив для УДТА директор Погребищенської гімназії Г. Ковальський. За формою це кореспондентська розповідь 3 елементами аналітики. Зокрема, автор зауважує, що «..большовики вважають своє становище дуже нетривким, підготовка до повстання роблять це становище критичним. Основними причинами цього являються: 1) голод, 2) повстання, які трохи на зіму притихли, а зараз вже відновилися й направлені головним чином до того, щоб деморалізувати червону армію наскоками на місця іi розположення, 3) маси, колоністи, які наслані з голодних губерній (до 50-60 родин на село, крім дітей, яких надсилалось партіями). 4) продналог і зловживання ім, 5), надзвичайно розвинена національна свідомість і 6) деморалізація, а скорше розчарованість у червоній арміі...». Далі Г. Ковальський розглядає означені причини докладно. У звіті директора Погребищенської гімназії є й такі розділи, як «Генуенська конференція», «Праця інтелігенціі», «Настроі населення», «В комуністичний партіі», «Церква», «Школа, «Дорожнеча», «Шляхи», «Нова економічна політика», «Вигляд міст» (Центральний державний архів вищих органів влади та управління України. Ф № 1113, опис № 1, справа № 18, 20.02.1919-05.07.1919 pp.). Зазначений вище матеріал має такі характерні ознаки: чітка структурованість контенту; широка тематична спрямованість; достовірність; аналітичність; емоційність.

Щоб мати уявлення, якими були інформаційні повідомлення у звітах Телеграфного Агентства, цитуємо повною мірою новину з розділу «Школа»: «В Киіві з 400 шкіл всіх типів працьовало 180. До Різдва навчання не було. Бастували учителі і професора університету вимагаючи виплату утримання. Большовики уступили й почали давати пайові й видали залеглости за $\frac{1}{2}$ року по 50.000 . Потім шла рубка дров. Після Різдва багато шкіл закрилося. Решта працювала. В університеті більш менш регулярні лекціі почалися 3 наступленням тепла. Підручників, пер, чорнила, оливців не мае... По маленьких містах $\mathrm{i}$ селах селяни «самоокупають» школи й вони працюють майже регулярно». Стилістику збережено. (Центральний державний архів вищих органів влади та управління України. Ф № 1113, опис № 1, справа № 18, 20.02.1919-05.07.1919 pp.).

Особливості зазначеного інформаційного повідомлення можна викласти за допомогою наступної схеми: 


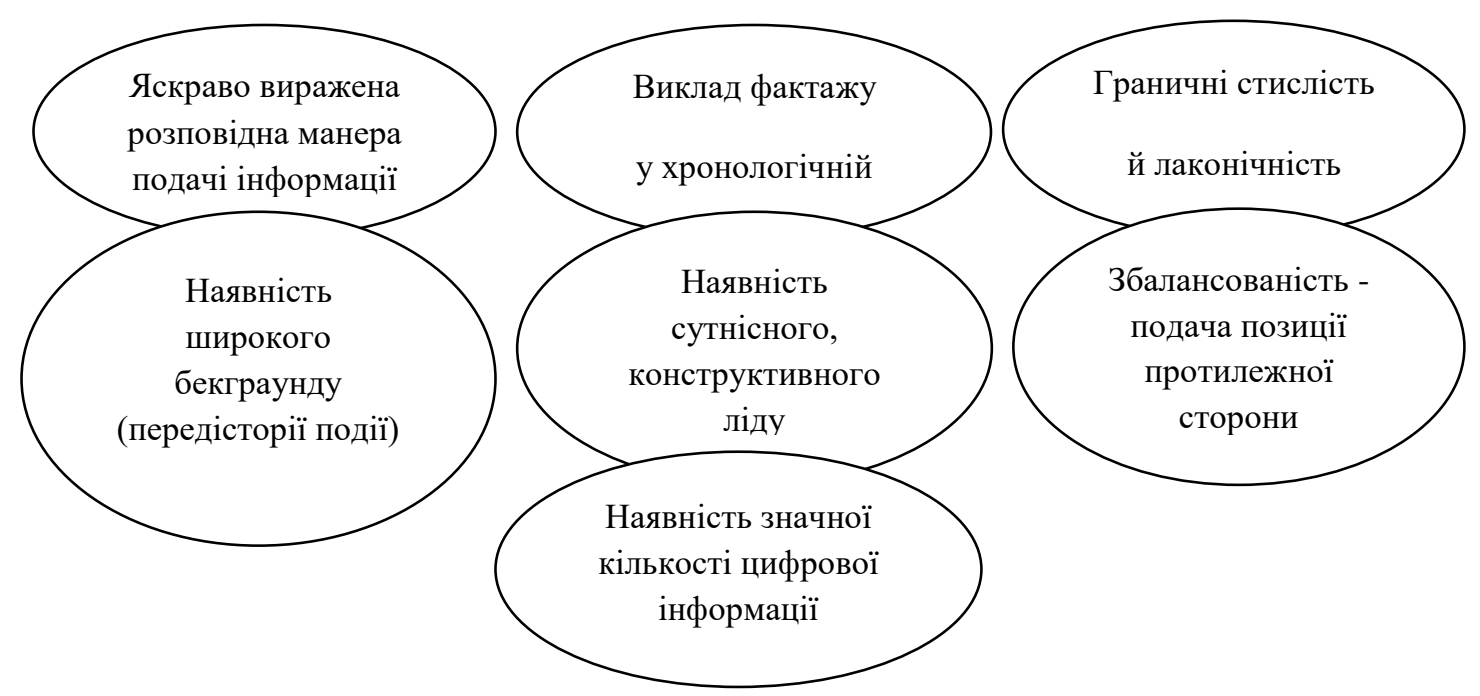

У трьох викладених вище матеріалах (перелік тем в обіжникові Українського Державного Телеграфного Агентства, звіт директора Погребищенської гімназії, новинне повідомлення у звіті Агентства) чітко простежується подібність ознак у системі «радіотелеграфний зв'язок» і системі «суспільне радіомовлення», про що вже частково згадувалося вище. Перша ознака - виражена суспільна спрямованість відомостей, друга ознака - орієнтованість на задоволення інформаційних запитів спільноти, третя ознака - намагання подати всі наявні точки зору щодо певної події чи явища, четверта ознака - розлогість тематичного складника, п'ята ознака - намагання виробити стандарти подачі інформації.

Окрім того, видається цілком логічним провести паралелі в системі «радіотелеграфний зв’язок» $\mathrm{i}$ системі «суспільне радіомовлення» із точки зору наслідування загальних принципів редакційної політики суспільного мовника, які $є$ так само очевидними, як і характерні ознаки обох систем. Насамперед ідеться про:

1. Універсальність поданої інформації - донесення до споживача виробленого контенту, що є для нього цікавим, цінним і корисним.

2. Незалежність - незаангажованість, об’єктивність інформації від політичних, комерційних й інших впливів.

3. Досконалість - діяльність на основі стандартів професійності, вироблення критеріїв якості.

4. Різноманітність - відповідність інформаційним запитам і потребам різних аудиторій про події, явища, процеси різних сфер життя.

5. Відповідальність - відкритість для громадського контролю, уміння пояснювати й виправляти помилки.

6. І Інноваційність - збагачення медійного середовища завдяки запровадженню новітніх технологій.

Отже, 3 огляду на тогочасну соціально-політичну обстановку контент, який передавався за допомогою радіотелеграфного зв'язку, повною мірою виконав завдання, що постають нині перед суспільним радіомовленням. Маємо на увазі створення такої інформації, якій би довіряла спільнота, 
вироблення цікавого й корисного продукту для всіх категорій населення, бути пов'язаним із життям усієї країни.

Повертаючись до теми функціонування радіотелеграфного зв'язку в УНР, не можемо не загострити уваги на документі високої суспільної ваги. Ідеться про лист Міністерства Закордонних Справ до Міністерства Пошт і Телеграфів від 02.06.1920 р. про звільнення України від більшовицької влади: «До Міністерства Пошт і Телеграфів У.Н.Р.. Департамент Поштовий, Відділ Міжнародний. 3 доручення п. Міністра Закордонних Справ Департамент Чужоземних Зносин М.3.С. у відповідь на Ваше письмо від 28/V ц.р. за ч. 1029 мае честь повідомити, що вся теріторія Украіни звільнена від большовиків на протязі часу починаючи від 25/IV ц.р. мае цивільну адміністрацію украінську. На тій території можна встановляти поштово-телеграфні установи і налагоджувати поштово-телеграфний зв'язок. Директор Департамету Чужоземних Зносин Шкільний (підпис нерозбірливо)» (Центральний державний архів вищих органів влади та управління України. Ф № 554, опис № 1, справа № 175, с. 6). Стилістику збережено.

Питання передачі інформації на відстань у межах країни, а також на закордонні терени набувало ледве не першорядної ваги. Саме цим можна пояснити лист Міністерства Пошт і Телеграфів до Пана Губерніяльного Комісара Поділля від 01.06 .1920 р. із проханням в екстреному порядку шукати телеграфне майно, яке могло залишитися від більшовиків: «Як відомо 3 певних джерел, в районі Жмеринки і в самій Жмеринці переховується, в приватніх руках багато Державного телеграфнотелефонного і радіотелеграфного майна, розграбованого при військових подіях. Прошу не відмовити в розпорядженні, аби там було проізведено трУси по крамницям і помешканням і якщо буде найдено вище згадане майно, то повернути його п.т. відомству, де зараз в ньому великий брак. Директор Технічного Департаменту Бутенко. Начальник Телеграфного Відділу Дашкевич (підписи)» (Центральний державний архів вищих органів влади та управління України. Ф № 554, опис № 1, справа № 175, с. 7). Стилістику збережено.

Після звільнення України від більшовицької влади питання щодо налагодження телеграфного зв'язку з різними місцевостями самої держави та з іншими країнами постало особливо гостро.

Відчайдушні пошуки уряду шляхів щодо встановлення комунікацій як у країні, так і поза іiі межами мають неоціненне значення для історії України, адже вони засвідчують глибоке, непереборне прагнення державників часів УНР будувати міцну й потужну державу. Важливою особливістю в їхній діяльності було те, що вони, як правило, не зволікали з розв'язанням численних проблем, не замовчували їх, а, навпаки, старалися використовувати будь-яку, бодай і найменшу можливість, щоб прислужитися розвиткові державності. Ця теза добре простежується в напрочуд важливому документі - Докладі Директора Технічного Департаменту Міністерства Пошт і Телеграфів Івана Бутенка. Виступ чиновника має промовисту назву - «Радіотелеграф на Украіні. Плян організаціі радіотелеграфного зв'язку для Державних Потреб в залежності від поступового звільнення територіі та програм відбудови на терені Украіни Державноі радіотелеграфноі сітки». Стилістику збережено. За його словами, в Україні не використовуються всі можливості радіотелеграфу через нерозуміння його специфіки, а також через відсутність фахового персоналу та відповідних матеріалів.

Іван Бутенко докладно ознайомлює урядовців із потенційними можливостями радіотелеграфу: «...торкаючись лише організаціi радіотелеграфу загально державного значіння слід виходити 3 таких властивостей радіотелеграфного зв’язку.

1. Передача відомостей можлива через великі терени в якому завгодно напрямкові, незалежно від того, чи на цих шляхах маються инші станціі чи ні. Тільки станціі новійших типів мають апаратуру значно простійшу і більш контактну.

2. Одержання відомостей, навіть великих дістанцій, провадиться при допомозі компактних i взагалі нескладних приладів. (Перешкоджує гроза і робота сторонніх станцій - майже завдяки не послідовній організаціі праці своіх же передаючих радіостанцій всіх відомств). 
3. Радіо телефон не значно ускладнюе апаратуру станцій новіших типів. Розмова може перехоплюватися всіма радіостанціями, до яких доходить проміння. Техніка в сучасному стані дозволяе певний регулярний зв'язок лище на середні дістанціi.

4. Радіотелеграфні станціі вимагають не тільки технічно підготовленого персоналу, але можуть обслуговуватися особами, вміючими передавати знаки по абетці Морзе. А це вміння набуваеться довгою практикою. Для Обслуговування радіотелеграфу досить лише одноі технично підготовленоі персоналіi.

5. Апаратура всіх радіостанці складаеться з великоі кількости ріжноманітних приладдів. Тому для забезпечення чинности без перерв, радіотелеграфна сітка мусить бути забезпечена спеціяльним та значним складом запасових частин» (Центральний державний архів вищих органів влади та управління України. Ф № 554, опис № 1, справа № 174, с. 5-7). Стилістику документа збережено.

Чітка й виразна артикуляція потреб уряду Української Народної Республіки в галузі радіотелеграфного зв'язку, професійний підхід щодо покриття територій, розрахунок приладів i комплектів станцій дають можливість дійти висновку, що чиновництво Міністерства Пошт і Телеграфів керувалося виключно національними інтересами, прагнуло поставити свою діяльність на користь країні та спільноті, а також, що є надто важливим, уміло спрямувати свої погляди в майбутнє. Усе це доводить, що урядовці не були тимчасовими клерками, позбавленими відповідальності за виконання своєї справи; це були діячі із глибоким державним мисленням, які вболівали за долю своєї країни.

\section{Висновки}

Вважаємо, що для з'ясування питання радіотелеграфного зв'язку Української Народної Республіки (УНР) 1917-1921 років як фундаментальної основи становлення суспільного радіомовлення України варто зважати на кілька тез.

1. Зародження радіо як технічного засобу зв'язку в 20-х роках ХХ століття стало знаковою подією в суспільному розвитку держави. Немає сумнівів у тім, що всі бурхливі події цього періоду: Перша світова війна, Жовтневий переворот у Петрограді, Українська революція, проголошення й утвердження діяльності Української Народної Республіки - безпосередньо позначилися на ідеологічно-змістових, структурно-композиційних, технологічних та інших трансформаціях радіотелеграфного зв'язку, а пізніше - на масовому регулярному радіомовленні та одному з його видів - інформаційному. Хоч у цей історичний проміжок часу про радіо як засіб масової комунікації можна говорити умовно, однак було закладено фундаментальну основу для розвитку регулярного радіомовлення упродовж XX - початку XXI століть і становлення суспільного радіомовлення другого десятиліття XXI століття.

2. Радіотелеграфний зв'язок потужним чином уплинув на проголошення, утвердження й функціонування Української Народної Республіки (УНР) 1917-1921 років. Саме завдяки йому УНР постала в країні та поза іiі межами як повноцінне, самодостатнє й суверенне державне утворення. Поширення важливої суспільно-політичної інформації засобами радіотелеграфу викристалізувалося в одне зі стратегічних завдань країни. Перемовини очільників уряду в службових потребах, обмін різними документами між міністерствами УНР за допомогою прямих проводів розглядаємо як напрацювання своєрідного радіотелеграфного контенту, що стало прообразом майбутнього інформаційного радіомовлення, у надрах якого визрівали передумови для запровадження суспільного мовлення. Завдяки продукуванню цього контенту було здійснено перші кроки із забезпечення вітчизняних і закордонних спільнот достовірною, повновичерпною інформацією про життєдіяльність молодої Української держави. Пройшовши тривалий і непростий шлях свого становлення, радіотелеграфний контент у подальшому зміг напрацювати суто радійні методи та прийоми подачі інформації, що не могло не позначитися на якісному наданні спільноті необхідних суспільно значущих відомостей. Саме надання спільноті якісної інформації й розглядаємо як наріжний камінь розвитку суспільного радіомовлення. 
3. Показовим є той факт, що в уряді УНР одним із перших було створено Міністерство Пошт i Телеграфів. Діяльність такої виконавської структури від початків проголошення УНР спричинила створення системи ефективних комунікацій першого українського уряду зі своїми громадянами, а також закордонними урядами та спільнотами. Урядовці УНР та очільник Міністерства як істинні державотворці надавали великого значення встановленню комунікаційних зв'язків між різними суб'єктами міжнародного права, що, безумовно, відкривало шлях Україні до європейського співтовариства та його демократичних надбань.

4. Виробництво значної кількості радіотелеграфного контенту, як-от: службових записок, службових листів, звернень директорів департаментів, завідувачів відділів, наказів, розпоряджень міністрів, заступників міністрів - уважаємо первинним інформаційним радіопродуктом, а також прообразом сучасних новинних радіоповідомлень. Яскравою подією тієї доби стало створення Українського Державного Телеграфного Агентства (УДТА), яке готувало розлогі звіти про події різних сфер життя України для української спільноти закордоном. За формою означені звіти нагадували газетні матеріали, були ще далекими від суто радійних кореспонденцій, однак найцікавіші з них усе ж таки передавалися за допомогою радіотелеграфу. Хоч ці пересилання й не мали належної періодичності, що робило їх непомітним явищем, але вони теж сприяли поступовому напрацюванню аудіальних форм подачі суспільно значущої інформації.

5. Немає сумнівів у тім, що радіотелеграфний зв'язок став предтечею формування й становлення суспільного радіомовлення України. Воно визнається важливим складником європейської культурної спадщини та сучасної розвиненої демократії. Радіотелеграф забезпечував суспільство в цілому контентом високої суспільної ваги, сприяючи зростанню соціальної, політичної й культурної активності громадян і згуртуванню суспільства, адже специфіка місії радіотелеграфного зв'язку відповідає специфіці місії суспільного мовника. Ідеться про загальнодоступність (здійснення перемовин, обмін документами тощо на всій території країни); поширення достовірної, повновичерпної інформації; забезпечення жанрово-тематичної розмаїтості контенту; сприяння збереженню та розвитку національної культури, цінностей та ідентичності; висвітлення суспільно важливих тем.

\section{Подяки}

Поява нашої статті зумовлена кількома чинниками, які вплинули на зміст, методологію й форму викладу матеріалу.

Насамперед висловлюю щиру вдячність своїм колегам: доцентам кафедри телебачення i радіомовлення Інституту журналістики КНУ ім. Тараса Шевченка Юрію Петровичу Слісовенкові та Віктору Івановичу Набрускові, у бесідах із якими визріла ідея дослідити означене питання, що впродовж багатьох років лишалося білою плямою у вітчизняному журналістикознавстві.

Наша вдячність і професорові Володимирові Івановичу Шкляреві, який повсякчас наголошував на важливості дослідження історії медіа крізь призму сучасних геополітичних і світоглядних викликів.

\section{Література}

Багиров, Э.Г, \& Ружников, В.Н. (1984). Основы радиожурналистики. (Учебное пособие). Москва: Издательство Московского университета.

Ваганова, О.В. (2003). Роль засобів масової комунікації у процесі глобалізації. (Автореф. дис. канд. політ. наук). Київ.

Василенко, В.А. (2014). Російсько-українська війна 2014 року: причини, перебіг та політикоправові оцінки. Украӥнський Тиждень, № 42, 28-42. 
Дубровин, В.Б. (1972). К истории советского радиовещяания. Издательство Ленинградского университета.

Слісовенко, Ю.П., \& Нагорняк, М.В. (2017). Радіовиробнищтво. (Навчальний посібник). Київ: ТОВ «ДРУКАРНЯ «БІЗНЕСПОЛІГРАФ».

Лизанчук, В.В. (2006). Основи радіожурналістики. (Підручник). Київ : Знання.

Литвин, В.М. (Ред.). (2007). Україна: політична історія. XX - початок XXI століття. Київ: Парламентське видавництво.

Миронченко, В.Я. (1984). Інформаційне радіомовлення на Україні. (Посібник). Київ: Видавництво при Київському державному університеті видавничого об'єднання «Вища школа».

Миронченко, В.Я. (1989). Інформаџійне радіомовлення. Управління. Організація. Планування. (Посібник). Київ: Видавництво при Київському державному університеті видавничого об'єднання «Вища школа».

Митрофанов, Н.Н. (1980). Радио Октября. Москва.

Нагорняк, М. (2019). Радіотелеграф УНР (1917-1921 рр.): зародження, основні характеристики, стильові особливості. Bulletin of Lviv University. Journalism series. Biсник Львівського університету. Серія Журналістика. Вестник Львовского университета. Серия Журналистика, 45, 142-150. DOI: http://dx.doi.org/10.30970/vjo.2019.45.9995

Ружников, В.Н. (1987). Так начиналось. Историко-теоретический очерк советского радиовещания. 1917-1928. Москва: Искусство.

Розпорядження міністра М. Шаповала. (31 грудня 2017 р., № 1013). Центральний державний архів вищих органів влади та управління України. (Фонд № 2592, опис №1, справа № 10, с. 6.).

Службова записка та звернення Панові Представникові Німецької держави. (4 квітня 1918 р. за № 982). Центральний державний архів вищих органів влади та управління України. (Фонд № 2592, опис № 1, справа № 10, с. 15).

Службова записка. (15 квітня 1918 р. за № 1329). Центральний державний архів вищих органів влади та управління Украӥни. (Фонд № 2592, опис № 1, справа № 10, с. 16-17).

Наказ про передачу Катеринославської дуженної радіостанції до Поштово-Телеграфного відомства. м. Київ. (27 липня 1918 р. за № 80). Центральний державний архів вищих органів влади та управління Украӥни. (Фонд № 3766, опис № 1, справа № 49, с. 189).

Листування (доклад) Пана Директора Загального Департаменту до Начальника БухгалтерськоГосподарчого відділу Міністерства Пошт і Телеграфів. (18 жовтня 1918 р.). Центральний державний архів вищих органів влади та управління Украӥни. (Фонд № 2592, опис № 1, справа № 10, с. 19).

Лист до Головного Управління Пошт і Телеграфів Міністра закордонних справ. (28 жовтня 1918 р. за № 1358). Центральний державний архів вищих органів влади та управління Украӥни. (Фонд № 2592, опис № 1, справа № 10, с. 21).

Звернення Директора Департаменту, Завідувача Загальним Відділом Міністерства Закордонних Справ до Міністерства Пошт і Телеграфів. (15 квітня 1918 р. за № 1347). Центральний державний архів вищих органів влади та управління України. (Фонд № 2592, опис № 1, справа № 10, с. 22). 
Службова записка Управління Міністерства закордонних справ до Міністерства Пошт i Телеграфів. (20 квітня 1918 р. за № 1541). Центральний державний архів вищих органів влади та управління Украӥни. (Фонд № 2592, опис № 1, справа № 10, с. 25).

Службова записка Міністерства закордонних справ до Телеграфного відділу Міністерства. травня 1918 р. за № 2604). Центральний державний архів вищих органів влади та управління України. (Фонд № 2592, опис № 1, справа № 10, с. 4).

Наказ про вживання в слові і пісьмі Державноі Українськоі мови по Поштово-Телеграфному відомству Міністра Внутрішніх. м. Київ. (26 липня 1918 р. за № 81). Центральний державний архів вищих органів влади та управління Украӥни. (Фонд № 2592, опис № 1, справа № 10, с. 188).

3вернення дирекції УДТА до Генерального Писаря. (28 березня 1918 р.). Центральний державний архів вищих органів влади та управління України. (Фонд № 1064, опис № 1, справа № 32, с. 17).

Обіжник Телеграфного Агентства. (28 березня 1918 р.). Центральний державний архів вищих органів влади та управління Украӥни. (Фонд № 1113, опис № 2, справа № 222, с. 56).

Звіти про поточну ситуацію в Україні. (20 лютого-5 липня 1919 р.) Центральний державний архів вищих органів влади та управління України. (Фонд № 1113, опис №1, справа № 18, стор. не позначені).

Лист Міністерства Закордонних Справ до Міністерства Пошт і Телеграфів про звільнення України від більшовицької влади. (02.06.1920р.). Центральний державний архів вищих органів влади та управління Украӥни. (Фонд № 554, опис № 1, справа № 175, с. 6).

Лист Міністерства Пошт i Телеграфів до Пана Губерніяльного Комісара Поділля. (01.06.1920 р.). Центральний державний архів вищих органів влади та управління Украӥни. (Фонд № 554, опис № 1, справа № 175, с. 7).

Доклад Директора Техничного Департаменту Міністерства Пошт і Телеграфів Івана Бутенка. Центральний державний архів вищих органів влади та управління Украӥни. (Фонд № 554, опис № 1, справа № 174, с. 5-7).

Про Українське радіо. (2021). Режим доступа: http://www.nrcu.gov.ua/About_UR)

Ухвалено новий закон про мову. Перелік основних положен (2021) Режим доступа: https://www.radiosvoboda.org/a/29903678.html

\section{Reference}

Bagirov, E.G, \& Ruzhnikov, V.N. (1984). Osnovbl radyozhurnalystyky. (Uchebnoe posobye) [Fundamentals of radio journalism. (Training manuals)]. Moskow: Yzdatelstvo Moskovskoho unyversyteta [in Russian].

Vahanova, O.V. (2003). Rol zasobiv masovoi komunikatsii u protsesi hlobalizatsii [The role of the media in the process of globalization]. Extended abstract of Candidate's thesis. Kyiv [in Ukrainian].

Vasylenko, V.A. (2014). Rosijsko-ukrayinska vijna 2014 roku: prychyny, perebig ta polityko-pravovi ocinky [The Russian-Ukrainian war of 2014: causes, course and political and legal assessments]. Ukrayinskyj Tyzhden - Ukrainian week, № 42, 28-42 [in Ukrainian]. 
Dubrovin, V.B. (1972). K ystoryy sovetskoho radyoveshchanyia [On the history of Soviet radio broadcasting]. Yzdatelstvo Lenynhradskoho unyversyteta [in Russian].

Yelisovenko, Yu.P., \& Nagornyak, M.V. (2017). Radiovyrobnytstvo. (Navchalnyi posibnyk). Kyiv : TOV «DRUKARNIA «BIZNESPOLIHRAF» [in Ukrainian].

Lyzanchuk, V.V. (2006). Osnovy radiozhurnalistyky [Fundamentals of radio journalism]. Kyiv : Znannia [in Ukrainian].

Litvin, V.M. (Ed.). (2007). Ukraina: politychna istoriia. KhKh - pochatok KhKhI stolittia [Ukraine: political history. XX - the beginning of the XXI century]. Kyiv : Parlamentske vydavnytstvo [in Ukrainian].

Myronchenko, V.Ya. (1984). Informatsiine radiomovlennia na Ukraini. (Posibnyk) [Information radio communication in Ukraine. (Posibnik)]. Kyiv: Vydavnytstvo pry Kyivskomu derzhavnomu universyteti vydavnychoho obiednannia «Vyshcha shkola» [in Ukrainian].

Myronchenko, V.Ya. (1989). Informatsiine radiomovlennia. Upravlinnia. Orhanizatsiia. Planuvannia. (Posibnyk). [Information radio communication. Management. Organization. Planning. (Posibnik)] [in Ukrainian].

Kyiv: Vydavnytstvo pry Kyivskomu derzhavnomu universyteti vydavnychoho obiednannia «Vyshcha shkola» [in Ukrainian].

Mitrofanov, N.N. (1980). Radyo Oktiabria [Radio October]. Moskow [in Russian].

Nagornyak, M. (2019). Radiotelehraf UNR (1917-1921 rr.): zarodzhennia, osnovni kharakterystyky, stylovi osoblyvosti [Radiotelegraph of the Ukrainian People's Republic (1917-1921): origin, main characteristics, stylistic features]. Visnyk Lvivskoho universytetu. Seriia Zhurnalistyka - Bulletin of Lviv University. Journalism series, $45, \quad 142-150$. DOI:http://dx.doi.org/10.30970/vjo.2019.45.9995 [in Ukrainian].

Ruzhnikov, V.N. (1987). Tak nachynalos. Ystoryko-teoretycheskyi ocherk sovetskoho radyoveshchanyia. 1917-1928 [That's how it started. Historical and theoretical essay on Soviet radio broadcasting. 1917-1928 ]. Moskow : Yskusstvo [in Russian].

Rozporiadzhennia ministra M.Shapovala.(31 hrudnia 2017 r., № 1013). [Order of Minister M.Shapoval]. Central State Archive of the highest authorities and administration of Ukraine. (Fund № 2592, description № 1, case № 10, p. 6) [in Ukrainian].

Sluzhbova zapyska ta zvernennia Panovi Predstavnykovi Nimetskoi derzhavy. (4 kvitnia 1918 r. za № 982). [Memorandum and address to the Representative of the German State]. Central State Archive of the highest authorities and administration of Ukraine. (Fund № 2592, description № 1, case № 10, p.15) [in Ukrainian].

Sluzhbova zapyska. (15 kvitnia 1918 r. za № 1329). Central State Archive of the highest authorities and administration of Ukraine. (Fund № 2592, description № 1, case № 10, p.16 -17) [in Ukrainian].

Nakaz pro peredachu Katerynoslavskoi duzhennoi radiostantsii do Poshtovo-Telehrafnoho vidomstva. m. Kyiv. (27 lypnia 1918 r. za № 80). [Order on the transfer of the Ekaterinoslav Duzhnaya radio station to the Post and Telegraph Office. m. Kyiv]. Central State Archive of the highest authorities and administration of Ukraine. (Fund № 3766, description № 1, case № 49, p.189) [in Ukrainian].

Lystuvannia (doklad) Pana Dyrektora Zahalnoho Departamentu do Nachalnyka BukhhalterskoHospodarchoho viddilu Ministerstva posht i telehrafiv. (18 zhovtnia 1918 r.). [Correspondence 
(report) of the Director of the General Department to the Head of the Accounting and Economic Department of the Ministry of Posts and Telegraphs]. Central State Archive of the highest authorities and administration of Ukraine. (Fund № 2592, description № 1, case № 10, p.19) [in Ukrainian].

Lyst do Holovnoho Upravlinnia Posht i Telehrafiv Ministra zakordonnykh sprav. (28 zhovtnia 1918 r. za № 1358). [Letter to the Main Directorate of Posts and Telegraphs of the Minister of Foreign Affairs]. Central State Archive of the highest authorities and administration of Ukraine. (Fund № 2592, description № 1, case № 10, p.21) [in Ukrainian].

Zvernennia Dyrektora Departamentu, Zaviduvacha Zahalnym Viddilom Ministerstva Zakordonnykh Sprav do Ministerstva Posht i Telehrafiv. (15 kvitnia 1918 r. za № 1347). [Appeal of the Director of the Department, Head of the General Department of the Ministry of Foreign Affairs to the Ministry of Posts and Telegraphs]. Central State Archive of the highest authorities and administration of Ukraine. (Fund № 2592, description № 1, case № 10, p.22) [in Ukrainian].

Sluzhbova zapyska Upravlinnia Ministerstva zakordonnykh sprav do Ministerstva Posht i Telehrafu. (20 kvitnia 1918 r. za № 1541). [Official note of the Office of the Ministry of Foreign Affairs to the Ministry of Posts and Telegraph]. Central State Archive of the highest authorities and administration of Ukraine. (Fund № 2592, description № 1, case № 10, p. 25) [in Ukrainian].

Sluzhbova zapyska Ministerstva zakordonnykh sprav do Telehrafnoho viddilu Ministerstva. (27 travnia 1918 r. za № 2604). [Official note of the Ministry of Foreign Affairs to the Telegraph Department of the Ministry]. Central State Archive of the highest authorities and administration of Ukraine. (Fund № 2592, description № 1, case № 10, p. 4) [in Ukrainian].

Nakaz pro vzhyvannia v slovi i pismi Derzhavnoi Ukrainskoi movy po Poshtovo-Telehrafnomu vidomstvu Ministra Vnutrishnikh. m. Kyiv. (26 lypnia 1918 r. za № 81). [Order on the use in words and letters of the State Ukrainian language by the Post and Telegraph Office of the Minister of Internal Affairs. m. Kyiv]. Central State Archive of the highest authorities and administration of Ukraine. (Fund № 2592, description № 1, case № 10, p. 188) [in Ukrainian].

Zvernennia dyrektsii UDTA do Heneralnoho Pysaria. (28 bereznia 1918 r.). [Appeal of the UDTA Directorate to the Secretary General]. Central State Archive of the highest authorities and administration of Ukraine. (Fund № 1064, description № 1, case № 32, p.17) [in Ukrainian]. Obizhnyk Telehrafnoho Ahentstva. (28 bereznia 1918 r.). [Circular of the Telegraph Agency]. Central State Archive of the highest authorities and administration of Ukraine. (Fund № 1113, description № 2, case № 222, p. 56) [in Ukrainian].

Zvity pro potochnu sytuatsiiu v Ukraini. (20 liutoho-5 lypnia 1919 r.). [Reports on the current situation in Ukraine]. Central State Archive of the highest authorities and administration of Ukraine. (Fund № 1113, description № 1, case № 18, pages not marked) [in Ukrainian].

Lyst Ministerstva Zakordonnykh Sprav do Ministerstva Posht i Telehrafiv pro zvilnennia Ukrainy vid bilshovytskoi vlady. (02.06.1920 r.). [Letter of the Ministry of Foreign Affairs to the Ministry of Posts and Telegraphs on the liberation of Ukraine from Bolshevik rule]. Central State Archive of the highest authorities and administration of Ukraine. (Fund № 554, description № 1, case № 175, p. 6) [in Ukrainian].

Lyst Ministerstva Posht i Telehrafiv do Pana Huberniialnoho Komisara Podillia. (01.06.1920). [Letter from the Ministry of Posts and Telegraphs to the Mr. Provincial Commissioner of Podillya]. 
Central State Archive of the highest authorities and administration of Ukraine. (Fund № 554, description № 1, case № 175, p.7) [in Ukrainian].

Doklad Dyrektora Tekhnychnoho Departamentu Ministerstva Posht i Telehrafiv Ivana Butenka. [Report of the Director of the Technical Department of the Ministry of Posts and Telegraphs Ivan Butenko]. Central State Archive of the highest authorities and administration of Ukraine. (Fund № 554, description № 1, case № 174, pp.5-7) [in Ukrainian].

Pro Ukrainske radio [About Ukrainian radio]. Retrieved from http://www.nrcu.gov.ua/About_UR)

Ukhvaleno novyi zakon pro movu. Perelik osnovnykh polozhen [A new law on language has been adopted. List of basic provisions]. Retrieved from https://www.radiosvoboda.org/a/29903678.html

\section{Радіотелеграфний зв'язок Украӥнської Народної Республіки (УНР) 1917-1921 років як фундаментальна основа становлення суспільного радіомовлення Украӥни}

Майя Нагорняк,

кандидат філологічних наук, доцент кафедри телебачення і радіомовлення Інституту журналістики Київського національного університету ім. Тараса Шевченка

(м. Київ, Україна)

Анотація

Метою статті було обрано вивчення питання, пов'язаного зі становленням українського начіонального радіомовлення, яке визначається часом проголошення й утвердження Української Народної Республіки (УНР) 1917-1921 років, на цій основі доведення того, щуо радіотелеграфний контент слугував прообразом сучасного суспільного радіомовлення Украӥни.

Методологія включала в себе застосування методів двох груп: наукові практичні методи - спостереження й опис; наукові теоретичні методи - формалізація, аналіз $i$ синтез, узагальнення, аналогія.

Результати дослідження дали можливість з'ясувати, щзо одним із перших кроків уряду УНР було створення Міністерства Пошт $i$ Телеграфів, яке повною мірою взяло на себе зобов'язання щуодо встановлення й налагодження комунікаційних зв'язків молодої Української держави як зі своїми співвітчизниками, так із закордонною спільнотою, урядами країн світу, щуо відбувалося завдяки виробництву радіотелеграфного контенту. Основними формами изого контенту були численні розпорядження, накази, виступи, відозви, службові записки тощзо, які вважаємо первинними інформаційними повідомленнями. Зважаючи на високу суспільну значущість радіотелеграфного контенту, його надзвичайну актуальність у суперечливу історичну добу, оперативне донесення до аудиторії, збалансований підхід у подачі інформації, $\epsilon$ всі підстави вважати його предтечею створення сучасного суспільного радіомовлення Украӥни.

Висновки. Радіотелеграфний контент УНР періоду 1917-1921 років став першим інформаційним продуктом молодої держави Україна. Завдяки продукуванню иього контенту було здійснено перші кроки із забезпечення вітчизняних $і$ закордонних інституцій, спільнот достовірною й повновичерпною інформацією про буремні події Першої світової війни та 
[SCTP] Social Communications: Theory and Practice, Vol. 13(2).

DOI: $10.51423 / 2524-0471-2021-13-2-5$

повоєнних років. Поширення важливої суспільно-політичної інформачї засобами радіотелеграфу можна розглядати як стратегічне завдання УНР. Пройшовши тривалий шлях свого становлення, радіотелеграфний контент зміг еволюиіонувати в суто радійні методи та прийоми подачі інформації в майбутньому, щзо не могло не позначитися на процесі якісного й ефективного забезпечення аудиторії необхідними суспільно значущими відомостями, який становить основу розвитку суспільного радіомовлення Украӥни.

Ключові слова: радіотелеграф, радіотелеграфний зв'язок, радіотелеграфний контент, інформаційне повідомлення, суспільне радіомовлення.

Submitted to the editor - 14.11.2021

Reviewed - 26.11.2021

Accepted for printing - 18.12.2021

Подано до редакиії - 14.11.2021

Рецензовано - 26.11.2021

Прийнято до друку - 18.12.2021 